\title{
Mental Retardation: Early Identification and Prevention
}

\author{
Mr. Mubashir Gull ${ }^{1}$
}

\section{ABSTRACT:}

Mental retardation is a serious intellectual disability. The diagnosis of Mental retardation in a child can trigger a range of emotional responses in parents \& across the whole family. Parenting a child with a Mental retardation is a very difficult task as lot of stress, frustration, and hopelessness is experienced by them. The need of the study is to determine the early identification steps and preventive techniques of the mental retardation so that immediate steps would be taken by the parents to prevent and control the disability.

Keywords: Mental Retardation, Identification, Prevention

Mental retardation (MR) refers to sub-average general intellectual functioning which originates during the development period of the child and is associated with impairment in adaptive behavior (Solanki et al. 2015). It is a genetic disorder manifested significantly below average overall intellectual functioning and deficits in adaptive behavior (Armates 2009). Mental retardation is characterised by impaired intellectual, adaptive functioning, and have an IQ less than 70 with difficulty in daily living activity (ADL). It is a condition of incomplete development of the mind, which is generally characterised by impairment of skills, and is manifested during the development period, which contributes to overall level of intelligence (ICD-10). The diagnosis of mental retardation in a child can trigger a range of emotional responses in parents \& across family system. For some, it will constitute a crisis that requires extraordinary psychological adjustment from parents and contains elements of harm, loss and weakness. For others, the birth of a disabled child will be viewed as an unfortunate event; it may further provoke psychological growth in some family members. The initial parental response may be a form of emotional disintegration. This may evolve into a period of adjustment and later into reorganisation of the family's daily life (Marcia 1982). Mental deficiency and maladjustment has become an alarming universal problem in this existing society. Down syndrome and fragile $\mathrm{X}$ syndrome often overlap with mental retardation. It is an incomplete or arrested development of mind of a person, which is characterised by sub-normality of intelligence (PWD ACT 1994). Mental retardation is a sub-average intellectual functioning and limitation in adaptive skills such as communication, self-care, social skills, health, safety and work and is manifested before the age of 18 years (AAMR 1994, 2002).

\footnotetext{
${ }^{1}$ Research Scholar, Department of Psychology, Aligarh Muslim University, Aligarh
} 
Mental retardation impediment in kids is frequently missed by clinicians. This condition may be as an isolated finding or as a part of a disorder, or more extensive issue (Daily, Ardinger \& Holmes, 2000). Reasons for mental retardation are various and include hereditary as well as environmental elements. In at least 30 to 50 percent of cases, physicians fail to focus etiology regardless of in-depth assessment (Baird \& Sadovnick, 1985). Diagnosis is highly dependent on a comprehensive personal and family medical history, a complete physical examination and a careful developmental assessment of the child. Aforementioned elements will guide suitable assessment and referrals to provide genetic counseling, resources for the family and early intervention programs for the youngsters (Rutter, 2006).

\section{CLASSIFICATION OF MENTAL RETARDATION}

Based on the DSM-IV TR (2004) and AAMR (1983), the operational classification for persons with mental retardation is as follows.

\begin{tabular}{|l|c|c|}
\hline \multicolumn{1}{|c|}{ Levels of Retardation } & $\begin{array}{c}\text { DSM-IV-TR } \\
\text { CLASSIFICATION }\end{array}$ & $\begin{array}{c}\text { AAMR } \\
\text { CLASSIFICATION }\end{array}$ \\
\hline Mild Mental Retardation & $50-55-70$ & $55-69$ \\
\hline Moderate Mental Retardation & $35-40-50-55$ & $40-54$ \\
\hline Severe Mental Retardation & $20-25-35-40$ & $25-39$ \\
\hline Profound Mental Retardation & Below 20 or 25 & $0-24$ \\
\hline
\end{tabular}

\section{EARLY IDENTIFICATION}

The first and most important step in the diagnosis of mental retardation is to conduct study of a comprehensive patient and his family history. Previous gynecologic and obstetric history has revealed infertility or fetal loss as identification (Matson \& Sevin, 1994). Assessment of maternal health status during pregnancy with the involved child should include questions regarding utilisation of tobacco, alcohol and drugs; lifestyle or other risks for sexually transmitted diseases; weight gain or loss; indications of contamination; serious illness or injury; and surgery or hospitalisation (Reiss, 1994; Szymanski, 1994). NIMH in 1998 developed a systematic method for identification and screening of mentally retarted children.

\section{(1) Prenatal procedure for identification of Mentally Retarted children}

- Blood tests should be carried out for detecting anemia, diabetes, syphilis and neural tube defects.

- Ultra Sonography should be carried out in the second trimester of the pregnancy for detecting certain disorders such as hydrocephaly, microcephaly, holoprocencephaly, prosencephaly and some cerebral lesions.

- Foetoscopy should be carried out during the second trimester of pregnancy for diagnosing physical anomalies, metabolic disorders or biochemical abnormalities.

\section{(2) Perinatal or Natal identification.}

- Peri-natal infections have long-term cognitive effects such as neonatal herpes simplex virus (HSV) and group B Streptococcus infection. 
- HSV (Herpes Simplex Virus) often has a long term neurological impairment such as MR.

- Group B streptococcus has meningitis which may display neurosensory impairment, and is acquired in utero at the time of delivery or during the first 7 days of life.

- Low birth weight $(<2500 \mathrm{gm})$ and preterm delivery $<37$ weeks is also associated with an increased risk of MR.

- LBW/PRE (Low birth weight or Preterm delivery) infants who were growth retarted at birth tend to have lower mean IQs than appropriate growth LBW/PRE (Sung et al. 1993).

\section{(3) Postnatal identification}

Post natal causes of mentally retarted are easily detectable than pre-natal and peri-natal causes.

- Exposure of the child to contaminated environment (such as lead, methyl- mercury, polychlorinated biphenyls etc.) can lead neurological damage.

- A severe accident which leads head injury can also impair cognition.

- NIMH Scenderabad in 1998 has developed quick screening schedule for identification of mental retardation in children

\section{NIMH Screening Schedule:}

\begin{tabular}{|llcl|}
\hline $\begin{array}{l}\text { Stage } \\
\text { No }\end{array}$ & Child's Progress & Normal Development & $\begin{array}{c}\text { Delayed Development } \\
\text { if not achieved by the period. }\end{array}$ \\
01 & Respond to name/voice & $1-3$ months & $4^{\text {th }}$ month \\
02 & Smile at others & $1-4$ months & $6^{\text {th }}$ month \\
03 & Hold head steady & $2-6$ months & $6^{\text {th } \text { month }}$ \\
04 & Sits without support & $5-10$ months & $12^{\text {th } \text { month }}$ \\
05 & Stand without support & $9-14$ months & $18^{\text {th } \text { month }}$ \\
06 & Walks well & $10-20$ months & $20^{\text {th } \text { month }}$ \\
07 & Talks in 2-3 word sentences & $16-30$ months & $3^{\text {rd } \text { year }}$ \\
08 & Eats/drinks by self & $2-3$ years & $4^{\text {th year }}$ \\
09 & Tells his name & $2-3$ years & $4^{\text {th year }}$ \\
10 & Has toilet control & $3-4$ years & $4^{\text {th } \text { year }}$ \\
11 & Avoid simple hazards & $3-4$ years & $4^{\text {th } \text { year }}$ \\
Other factors & & No \\
12 & Has fits & Yes & No \\
13 & Has physical disability-what? & Yes & \\
\hline
\end{tabular}

\begin{tabular}{|c|c|c|c|c|}
\hline S. no & Name of instrument & Administration time & Age range & Author's Name \\
\hline 01 & $\begin{array}{l}\text { DST (Developmental } \\
\text { Screening Test) }\end{array}$ & $10 \mathrm{~min}$. & $1-15$ years & $\begin{array}{l}\text { J. Bharat Raj } \\
(1977.1978,1983)\end{array}$ \\
\hline 02 & Gesell Drawing Test & $15 \mathrm{~min}$. & $1-8$ years & $\begin{array}{l}\text { Verma, Dwarka \& } \\
\text { Kaushal (1972) }\end{array}$ \\
\hline 03 & $\begin{array}{l}\text { Vineland Social Maturity } \\
\text { Scale }\end{array}$ & 15-20 min. & $0-15$ years & Malin (1970) \\
\hline
\end{tabular}




\section{PREVENTION}

"Prevention is better than cure." The wisdom of this saying is that a little effort in the early stage of the problem would help us to solve the problem before it becomes too complicated. This principle is always observed by wise people who achieved success in their lives and those who fail to recognise this principle have to suffer even though they are intelligent and hard working. Based on the principle of early identification, the prevention of mental retardation is paramount. Prevention refers to the measures taken at the early stage to decimate the disability. Some of the early preventions techniques noted by Baraff et al.1993. Bushan et al. 1993., Stagno \& Whitley 1985 are.

\section{(1) Prenatal preventions.}

- Avoid hard physical work such as heavy loads, climbing stools and chairs, walking on slippery grounds etc.

- Avoid unnecessary drugs and medication.

- Avoid smoking, consuming alcohol and chewing tobacco.

- Avoid sexual contact with the person having venereal disease.

- Take precautions against lead poisoning.

- All pregnant women should take tetanus injections.

- Regular medical checkup in case of swelling of feet, fever, difficulty in urinating, bleeding from vagina and yellowness of eyes.

\section{(2) Perinatal or Natal Preventions.}

- Delivery should take place in a hospital where all the facilities are available.

- If the baby didn't cry immediately after birth, resuscitation measures should be undertaken at once.

- Babies born with (> 2.5KG) may need Neonatal care.

- In case if the head of the baby is too small or too large physician should be consulted.

- Brest feeding should be started immediately after birth.

\section{(3) Postnatal Preventions.}

- Don't allow a child to have a contact with paint, lead, newsprint ink etc.

- Every child should be immunized against infectious disease.

- Precautions should be taken against head injury and accidents.

- Ensure that the child gets a well balanced diet and clean drinking water.

- Don’t slap a child in the face. It may lead injury of the ear drum.

\section{CONCLUSION:}

Mental retardation is a genetic disorder manifested significantly below average overall intellectual functioning and deficits in adaptive behavior. Various natural, hereditary or different elements can result in mental retardation. It is better to stop something bad from happening than to deal with it after it has happened. So before identification of the stressful situation like birth of a mentally retarted child in family, parents particularly mothers should prevent themselves from 
alcohol, smoking and other toxic substances. They should avoid sexual contact with the person having venereal disease, unnecessary drugs and medication also. The base of the mental retardation either starts because of hereditary or from the mother's womb and then there is a little chance from accidents too.

\section{REFERENCES}

1. American Association of Mental Retardation (1992). Mental retardation definition classification, and system of supports $\left(9^{\text {th }}\right.$ ed.) Washington, DC: American Association on mental retardation.

2. Armates,V. (2009). Mental retardation: definitions, etiology, epistemology and diagnosis. Journal of sports \& health research.1(2), 112-122.

3. Baraff. L.J., Lee. S.I., \& Schriger. D.L. (1993). Outcomes of bacterial meningitis in children: A meta-analysis. Pediatrics infection and disease Journal. (12), 389-394.

4. Baird, P. A. \& Sadovnick, A. D. (1985). Mental retardation in over half-a-million conservative livebirths: An epidemiological study. American Journal of Mental Deficiency, 89, 323-330.

5. Bhushan V., Paneth N., \& Kiely JL. (1993). Impact of improved survival of very low birthweight infants on recent secular trends in the prevalence of cerebral palsy. Journal of mental retardation and developmental disability (91), 1094-1100.

6. Daily, D.K., Ardinger, H.H., \& Holmes, G.E. (2000). Identification and evaluation of mental retardation. Am Fam Physician; 62(5):961-963.

7. Marcia. A. C. (1982). Impact of a handicapped child on the family. Yale-New Haven Teachers Institute 455 Wintergreen Ave. New Haven, Conn

8. NIMH. (1998). A Manual of Rehabilitation Workers, Secunderabad.

9. Matson, J. L ., \& Sevin, J. A. (1994). Theories of Dual Diagnosis in Mental Retardation. Journal of Consulting and Clinical Psychology, 62(1): 6-16.

10. Rutter, L.Q. (2006). First Diagnosis of Severe Mental and Physical Disability: A Study of Doctor- Parent Communication. Journal of Child Psychology \& Psychiatry, 35(7): 12731287.

11. Solanki, J., Khetan, J., Gupta, S., Tomar, D., \& Singh, M. (2015). Oral rehabilitation \& management of metally retarted. Journal of clinical \& diagnostic research, 9(1).1-6.

12. Stagno. S., \& Whitley. R. J. (1985). Herpesvirus infections of pregnancy. Part II: Herpes simplex virus and varicella-zoster virus infection. The New England journal of medicine. $313,1327-1330$.

13. The International Classification of Diseases $10^{\text {th }}$ Revision ICD-10 (1996). Guide for Mental Retardation, division of mental health and prevention of substance abuse, World Health Organization, Geneva 